\title{
Potential Future Managers and Their Opinion on the Issue of Diversity, Inclusion and Their Possible Use in Management
}

Jirincová Milena

\begin{abstract}
This paper refers to the issues of diversity and inclusion because they represent a possible innovation in the field of management and business. Over the last years, there have appeared some organizations that take care of justice and supporting diversity in employment. This phenomenon is applicable to strategic management, human resource management and business, too. The labour market situation is ever-changing and brings new problems but also new challenges and opportunities for companies and their management how to increase their competitiveness. The main aim of this paper is to describe the opinion on diversity and inclusion of young people, specifically university and high school students of economic disciplines because they are potential managers or workers to occupy higher positions and their attitude could influence the future state of using diversity management and fair treatment with employees. Further aim is to work out a brief theoretical framework and to describe the current state of diversity and inclusion in the Czech Republic. In this paper, there are used methods as literature review, questionnaire survey, frequency comparison, Chi-squared test, and Mann-Whitney test. The paper includes work with secondary (statistical and theoretical) data but especially with primary data based on a questionnaire survey conducted by the author that is focused on exploring student's opinion on diversity, diversity management and benefits of using diversity in business, opinion on discrimination in the Czech Republic, or quotas for women in decision-making bodies.
\end{abstract}

Key words: diversity, equality, inclusion, management, future managers

\section{INTRODUCTION}

Inclusion and diversity become an important part of current society and world politics. Due to the current state of globalization, opening markets and demographic changes there is increasing diversity of population and of course diversity of labour force. The diversity could be the cause of discrimination, exclusion and conflicts in society and also in the work environment. However, it is important to realize that the diversity could be also an opportunity for business and management. Managing diversity could be very beneficial for whole economy in case of clever use. Many foreign companies have already implemented diversity management into their strategies but in the Czech Republic there is diversity management just early-stage in the field of practice and science too. Therefore there is a space for innovation and research.

It is important to explore the current state of diversity in the Czech Republic and to know what types of diveristy are the most significant and usable in management of Czech organizations. It is interesting to focus on the opinion of young people (possible future managers or executives) on the issues of diversity, diversity management, their benefits and problem of inclusion because these people will probably create the future shape of management. 


\section{RESEARCH DESIGN}

This paper uses the outputs from author's own research that is a combination of several methods. Methods and the main goals are described in further paragraphs.

\subsection{Research goals}

The main goal of this research is to explore the opinion of potential future managers on diversity and inclusion in the Czech Republic focusing on the field of business, management and labour market. The next goal is to assess the differences and dependences in their opinions. The partial goal is to describe a situation of diversity and inclusion in the Czech Republic and the current state of law and measures for equal treatment with employees.

The main research questions were: What discrimination is the most widespread in the Czech Republic according to potential future managers? What specific groups of population do suffer discrimination the most according to potential future managers? What benefits can diversity bring in business according to potential future managers? Or what is their opinion on quotas for women in decision-making bodies? Complementary research question were: What is diversity and what benefits can bring for companies? What is the current state of diversity of population in the Czech Republic? What are the measures for ensuring inclusion and equal treatment with employees in the Czech Republic?

\subsection{Research methods}

First of all there was conducted a "desk research" by studying secondary data from printed and non-printed information sources relevant to the topic of diversity, inclusion and management. There were also used quantitative and qualitative data from resources of European Commission, Eurostat and Czech Statistical Office.

Primary data in this paper were gained from author's "field research" that was conducted by questionnaire survey among students with economic field of study. The data were analysed and assessed by statistical indicators of frequency and mean. Some research questions were tested by Chi-squared test and one research question was verified by Mann-Whitney test for two unrelated samples. For obtaining data and data processing there were used an application Google Docs and MS Excel.

\section{THEORETICAL FRAMEWORK}

This paper is mainly focused on diversity and diversity management in the Czech Republic. These items are closely connected and there were used different foreign and Czech sources to briefly describe them. First of all there has to be defined the item of diversity, its dimensions and basic elements. Then author will focus on managing diversity (diversity management) and the benefits that can be brought by diversity to business.

\subsection{Diversity dimensions and its basic elements}

For the purposes of this paper diversity could be defined as a collective mixture characterized by differences and similarities that are applied in pursuit of organizational objectives. (Roosewelt, 
1996, Roosewelt, 1999). Risberg \& Sogerberg (2008) define diversity as a mix of differences, similarities and tensions that exist among the elements of a collective mixture.

Hubbard (2004) has noted four independent and sometimes overlapping aspects of diversity: workforce diversity, behavioral diversity, structural diversity, business and global diversity. Workforce diversity means composition of organization's employees, behavioral diversity containts work, thinking or learning styles, structural diversity encompasses interactions across organization's hierarchy, business and global diversity includes segmentation of customer markets. All of these aspects can appear in organization environment and managers should know about them.

According to Hubbard (2004) and Bedrnová \& Nový (2007) diversity can be understood as a variety of labour force from the point of view of two basic dimensions- primary dimension and secondary dimension (see Fig. 1). Primary dimension of diversity contains characteristic as age, ethnicity or race, gender, mental and physical abilities and sexual orientation. These characteristic are often changeless and have a great influence on the working life. Secondary dimension encompasses elements as communication style, socio-economic status, beliefs, education, geographic location, work background etc.

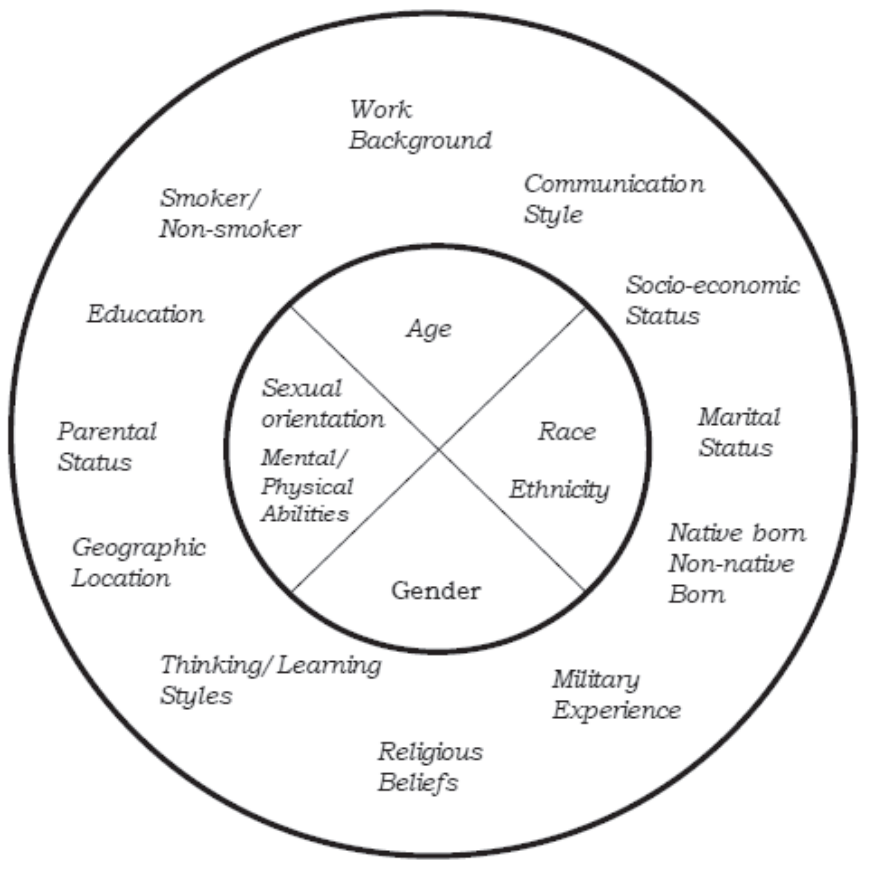

Fig. 1 - Primary and secondary elements of diversity. Source: Hubbard, 2004, p.32.

\subsection{Managing diversity}

Managing diversity can be also called diversity management (DM). "Diversity poses complex challenges, however, because it can have positive as well as negative effects on performance." 
(Knippenberg \& Ginkel \& Homan, 2013, p. 183) Therefore DM is one of the challenges for global HR executives. (Ananthram \& Chan, 2013) Diversity management comes from the USA and it was developed in 1980s as a response to problems of the labour market. (Kirton \& Greene, 2010, Roosewelt, 2006) Now diversity management is spreading in the world but it is important that diversity management in Europe is implemented in the society especially as a proactive concept, not as an affirmative action in the USA. (Eger et al., 2012) It is a process of planning, organizing, directing and supporting the diversity in a way that brings a measurable difference to organizational performance. (Hubbard, 2004) Diversity management is characterised as a sistematic procedure used by companies when they decide to work with diversity and use it as a strategic advantage. (Bedrnová \& Nový, 2007) Diversity management should be able to use the workforce diversity for fulfillment company's goals and reaching a higher competitiveness.

DM should be a part of strategic management and mission of the company. Strategic diversity management is a craft for enhancing the way people make quality decisions in situation where there are critical differences, similarities and tensions and anyone can learn to use it. (Roosewelt, 2006)

\subsection{Benefits of diversity}

Effective managing diversity can bring many benefits for the company. Hubbard (2004), Bedrnová \& Nový (2007) or Lančarič \& Savov \& Chebeň (2012) note some benefits such an improvement of company's performance, increasing the quality and effectiveness of the workforce, enhancement flexibility and creativity, improvement the quality of decision making and organizational learning, better recruitment and retention of skilled and talented people, increasing customer understanding as well as strengthening market positions.

These benefits are available not only for large companies that have resources for funding of diversity policy. Managing diversity can offer small and medium enterprises a cost-effective approach to overcoming the challenges by attracting the best talent and increasing market competitiveness through skills and greater innovation. In 2008 there was conducted a research (SME Diversity Survey) among 1200 small and medium-sized enterprises (SMEs) in European Union (EU) and it shows, that almost $80 \%$ of respondents answered they recognised business benefits when employing a diverse workforce. As it is obvious from Fig. 2, almost 60\% of SMEs suggested it was because diversity policies enable the recruitment and retention of quality employees, approximately $40 \%$ recognised a connection between diversity, creativity and innovation. Other benefits according to SMEs are reducing absenteeism and employee turnover, reducing time waste and lost, increasing client loyalty, increasing brand value and access to new markets etc. (European Commission, 2008) 


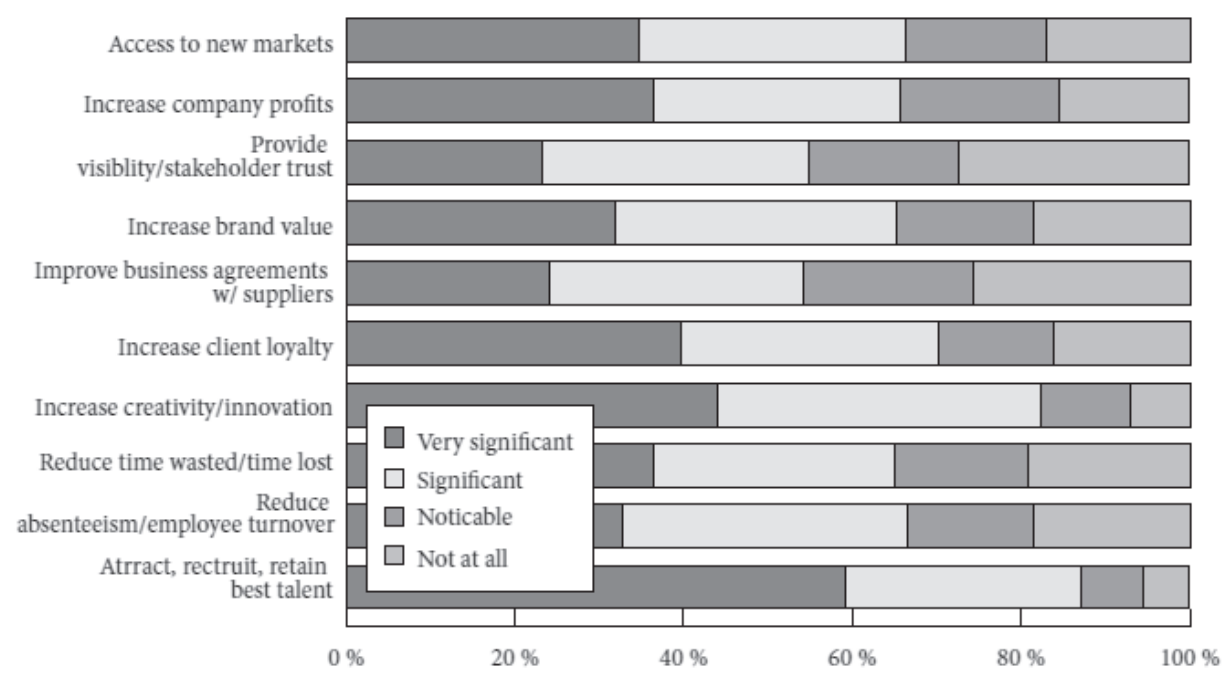

Fig. 2 - SMEs benefits associated with diversity. Source: European Commission, 2008.

\section{DIVERSITY AND INCLUSION IN THE CZECH REPUBLIC}

Diversity in the Czech Republic is not so significant as for example in the USA or in the UK where managing diversity and inclusion is at a high level. Nevertheless there can be seen a space for work with diversity, especially with age and gender diversity that is really high in CR. Number of women in relation to 100 men was 103.7 in 2012. (CZSO, 2012b) The unemployment rate of women was $8.1 \%$ in January 2013, unemployment rate of men only $6.1 \%$. (CZSO, 2013) There also still exists gender pay gap in the Czech Republic, in 2011 it was 21\%. (CZSO, 2011a) Share of population aged more than 65 years is still increasing and in 2011 it was $15.6 \%$. There is still increasing also median age of population. (CZSO, 2011b) Employment rate of older workers (55-64 years old) has mostly an increasing trend but its amount is still under 50\% and this could be problem in the future. (CZSO, 2011c)

However other elements of diversity as ethnicity or disability are becoming also very significant due to opening markets and tightening labour laws. Number of foreigners in the Czech Republic was increasing since 2002 to 2010, in the last years it is fluctuating but there can be expected its increase in the future. (CZSO, 2012a) There are about 1 million disabled people in CR, of which approximately 350000 are able to work. (Paříková, 2012)

There are many reasons for employing a diverse workforce- moral, business and legal. (Kirton \& Greene, 2010) Problem of inclusion is solved at the level of national governments and also at the level of EU policy- they try to decrease rate of discrimination and exlusion of vulnerable groups by different legislation. Countries where diversity management does not have so long history (such as the Czech Republic) often have problems with inclusion and employment of diverse workforce except the legal obligation. The companies do only what they have to do by the law but nothing more. However, it can be seen an improvement for example in the field of social responsibility that became very popular among Czech companies in the last few years and which sometimes includes also the diversity management and equal treatment with employees. 
Czech Republic has own legal instruments how to support inclusion and diversity and it also adopts proposals from EU. Principle of equality is defined for example in Labour Code, Employment Act or in Anti-discrimination Law. Moreover Czech government is supporting inclusion also by another instruments than just by law (programmes for Roma inclusion, measures for equality of men and women, programmes for disabled people etc.). According to European Commission (2010) the key challenges in the field of inclusion and equality are for example to promote the active inclusion in society and the labour market of the most vulnerable groups, to overcome discrimination and increase the integration of people with disabilities, ethnic minorities, immigrants and other vulnerable groups and to promote the integration of Roma.

Despite all measures there still exists a certain degree of discrimination based on different elements of diversity. The state of discrimination is different in EU countries. The Fig. 3 shows the most widespread types of discrimination in the CR (according to Czech population) compared with EU-27 average (opinion of EU citizens).

In the last year there has appeared an idea of introducing quotas for women on boards of the largest listed companies in EU. European Commission proposed legislation with the aim of attaining a $40 \%$ objective of the under-represented sex in non-executive board-member positions in publicly listed companies. (European Commission, 2013) Finally it was not accepted but it provoked debate in many European countries.

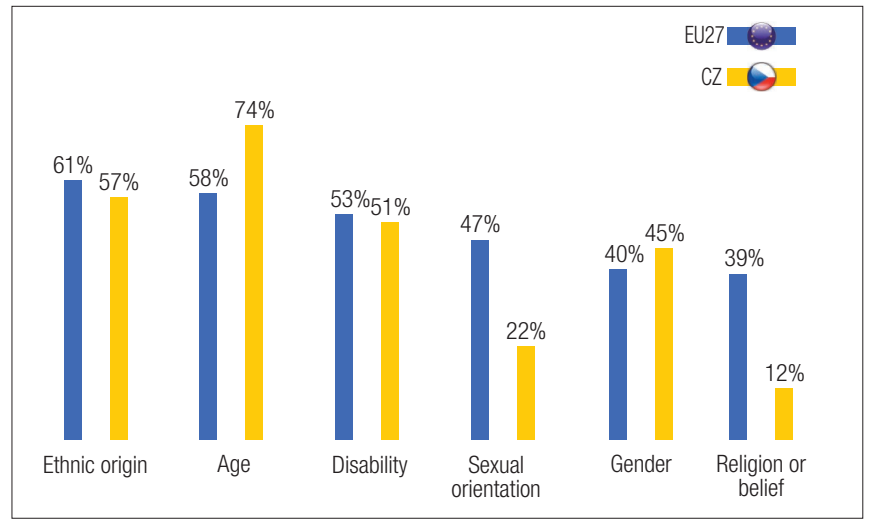

Fig. 3 - Perception and experience of discrimination in the CR and EU-27. Source: European Commission, 2009.

\section{QUESTIONNAIRE SURVEY AND ITS OUTPUTS}

The questionnaire survey was conducting during the year 2012- from June to October. Respondents answered 11 closed questions and 3 open questions. Questions are divided into two parts- the field of diversity and its managing and benefits and the field of discrimination and inclusion. The classification items in questionnaire are gender and age because these are the most significant elements of diversity in the Czech Republic and it is interesting to compare answers just of these groups. The questionnaire was partly distributed in person and partly electronically by means of an online form of the Google Docs system. As a method of data collection was used selective survey- the selective file was determined randomly. 


\subsection{Sample characteristics}

Total 150 respondents participated in the survey. These respondents are students of economics who have higher probability to become managers in the future or to get higher job positions. These respondents are high school or university students of economic disciplines and they predominantly study the Business Academy in Domažlice and the Faculty of economics in Pilsen. Among these respondents there are only 41 men and 109 women, apparently because students of economics are mostly women. They are divided into three parts by age: students 15-20 years old, students aged between 21 and 25 years (the largest group) and students and fresh graduates aged 26 and more. Their absolute numbers are seen in Fig. 4.

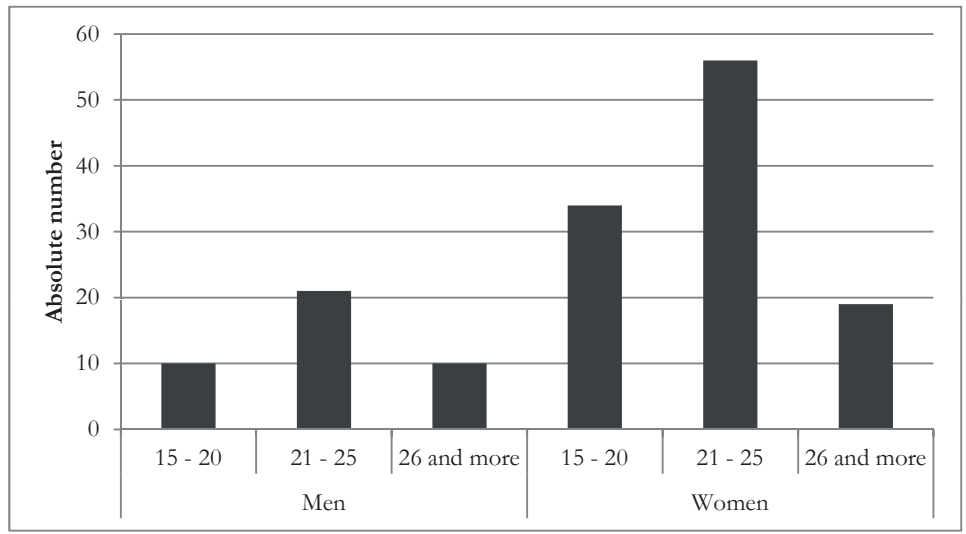

Fig. 4 - Absolute numbers of men and women by age. Source: own processing, 2013.

\subsection{What does it mean "diversity" by respondents?}

The first question in questionnaire was about the term diversity and its meaning. Respondents mostly knew what does it mean the term diversity and they had a clear opinion on its utilization and benefits. Only 19 from them did not know exactly how to define diversity. Their answers were often associated with management and business.

The next question was concerned concretely with diversity management where respondents should choose if they had something heard about diversity management and where. Results of the survey shows that this issue is not so known as diversity. Just 104 (from 150) respondents had never heard about it but when they should describe in their own words what does it mean, they mostly defined the nature right.

\subsection{The most widespread type of discrimination by respondents}

Respondents answered the question what type of discrimination is the most widespread in the Czech Republic by them. All groups answered that the most often is the discrimination based on age and the least common is the discrimination of homosexuals. Differences in answers between partial groups are seen in Fig. 5. There was not proven any statistical dependence (between gender and responses and between age and responses). This was tested by Chi-squared test of independence and the test statistic (gender- 0,5202; age- 0,00015) was always lower than the critical value (gender- 2,4753; age- 0,5142 ). Hypothesis $\mathrm{H}_{0}$ could not be rejected and there is no 
dependence between the characteristics. This fact is seen also from the graphs. All columns are following approximately the same trend. The figures are in percent because absolute numbers are not comparable due to the different sizes of respondents groups. The left chart shows relative frequency of answers of women and men, the right chart represents relative frequency of answers of three age groups (15-20, 21-25, 26 and more).

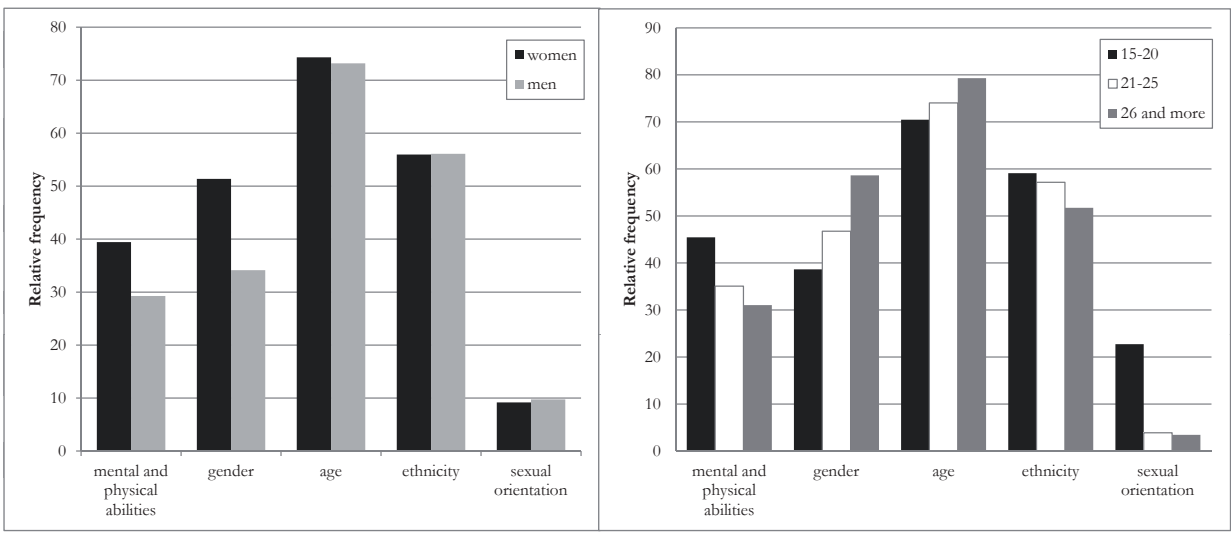

Fig. 5 - The most widespread discrimination in CR by women, men and individual age groups. Source: own processing, 2013.

There are seen (in Fig. 5) no differences between answers of men and women in fields of age, ethnicity and sexual orientation but their answers vary in case of mental and physical abilities and gender issue. Opinion on gender discrimination is predicable, greater percentage of women feel that discrimination based on gender is widespread. Women more than men also feel the problem of discrimination of disabled people. The biggest difference between younger (15-20) and older (26 and more) students are in answers by sexual orientation and mental and physical abilities.

\subsection{The most discriminated groups of population by respondents}

After the most widespread type of discrimination respondents should decide what specific group of population is the most suffering of discrimination. Possibilities were old people, young people and graduates, women, men, foreigners, homosexuals or disabled people. Answers by gender and age are seen in Fig. 6. Also in case of gender there was not proved any statistically significant dependence by Chi-squared test of independence. Test statistic $(0,0013)$ is lower than critical value $(0,2341)$. However there is a statistically significant dependence between age of respondents and their answers on this question. Test statistic $(8,6758)$ is higher than critical value $(0,8621)$, therefore hypothesis $\mathrm{H}_{0}$ is rejected. 


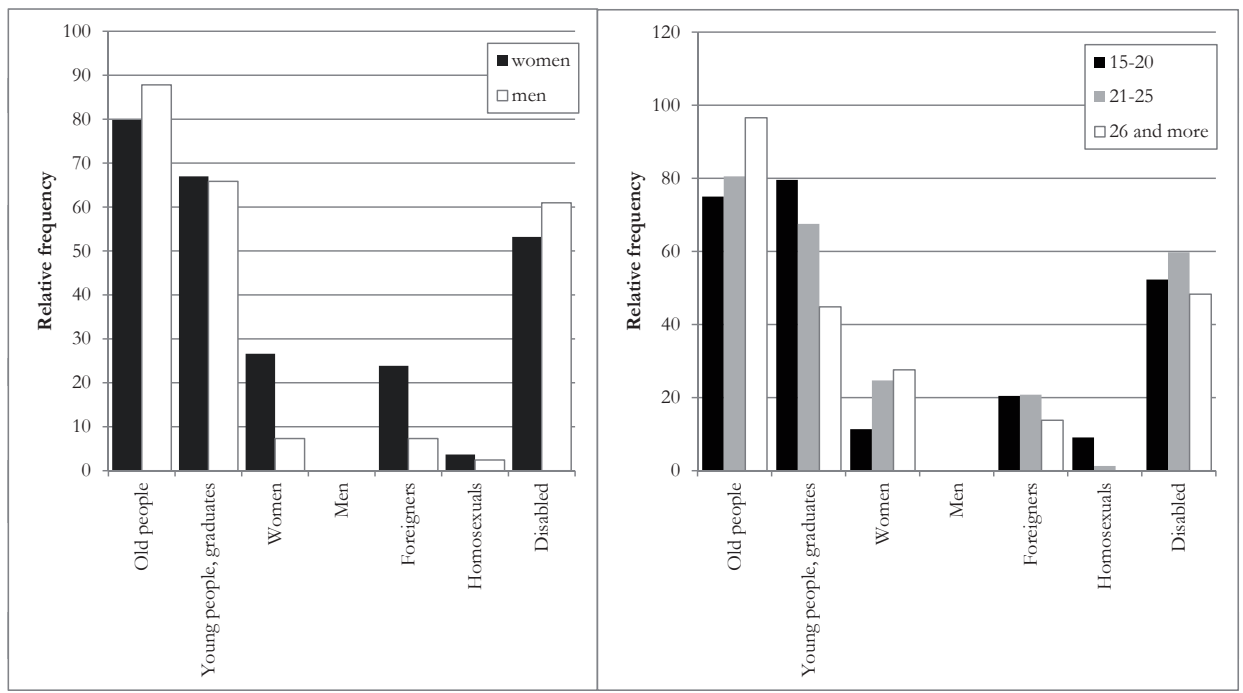

Fig. 6 - The most suffering groups from discrimination by womenm, men and individual age groups. Source: own processing, 2013.

No respondents answered the possibility of men. According to these students men are not suffering from discrimination. The most vulnerable groups are old people, young people and disabled people. The biggest difference between answers of male and female respondents are in question about women and foreigners. Only few male respondents think that women and foreigners suffer from discrimination. Expectable difference is between answers of younger and older group, where older respondents think older people are more suffering, younger respondents answered more the possibility of young people and graduates.

\subsection{Benefits of diversity by respondents}

In this field respondents should mark what benefits can diversity bring to business. They had a possibility of multiple answers, therefore the numbers are higher than number of respondents. Their responds (absolute numbers) are illustrated in Fig. 7.

Number 1 in the chart represents benefit Improving company image, 2- Increasing motivation, satisfaction and performance of employees, 3- Recruiting the best talents, 4- Increasing creativity and innovation, 5- Increasing customer loyalty, 6- Increasing company profit, 7- Access to new markets, reaching new customers, 8 - No benefit.

From the Fig. 7 it is obvious that the most perceived benefit of diversity by future managers is 4- Increasing creativity and innovation, the second greatest benefit of diversity is 2- Increasing motivation, satisfaction and performance of employees and the third is 1-Improving company image. Some respondents answered that the diversity does not bring any benefits (number 8 in chart). Some results are similar as the result of EU research in Fig. 2., especially item of Incresing creativity and innovation. 


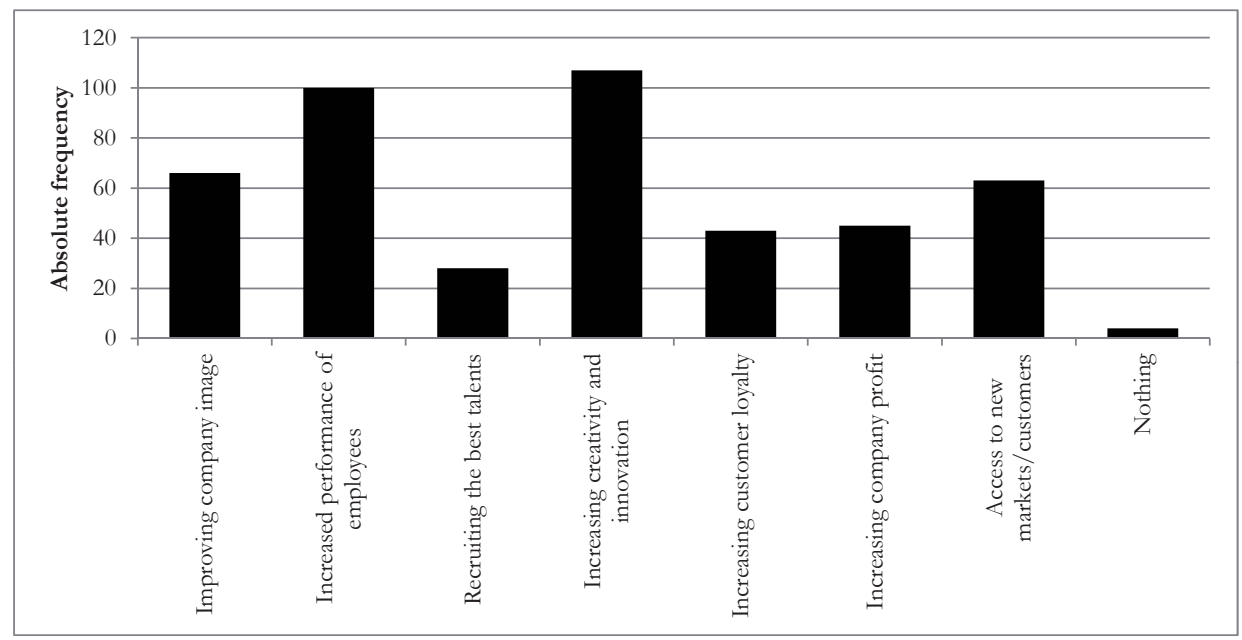

Fig. 7 - Benefits of diversity by respondents. Source: own processing, 2013.

\subsection{Quotas for women on board by respondents}

Issue of quotas is very argueable. Respondents from this questionnaire survey answered more positive because women have predominance among respondents and women answered mostly positive. Most women answered definitely yes or rather yes, most men answered definitely not or rather not but there are also few women and men who have opposite view than their counterparts.

There could be defined a hypothesis that the answers are dependent on who is answering the question- men or women. It was used the Mann-Whitney test for two unrelated samples because there are compared answers of only two groups- men and women. The Mann-Whitney test verifies that the two unrelated samples come from the same base file or files with the same distribution. The Mann-Whitney test is one of the strongest non-parametric tests and also one of the most used. (Blatná, 1996) The samples size was too large so it was necessary to approximate a normal distribution and then the test statistic could be calculated. Results of calculations are seen in Tab. 1. Test statistic is compared with the standard normal quantiles at a significance level of $5 \%$ or with a quantiles at a significance level of $1 \%$. In Tab.1 it is obvious that there exists a statistically significant difference between women and men answers at a significance level of $5 \%$ and at a significance level of $1 \%$ too. It can be confirmed the hypothesis that answers are dependent on who is answering.

Tab. 1 - Results of calculations of Mann-Whitney test. Source: own processing, 2013.

\begin{tabular}{|c|c|c|}
\hline Test statistic $\left(\mathrm{U}_{0}\right)$ & $\begin{array}{c}\text { Normal quantile }(\mathrm{U} \alpha) \text { at a } \\
\text { significance level of } 5 \%\end{array}$ & $\begin{array}{c}\text { Normal quantile }(\mathrm{U} \alpha) \text { at a } \\
\text { significance level of } 1 \%\end{array}$ \\
\hline $5,65491068>$ & 1,644854 & 2,326348 \\
\hline
\end{tabular}

It is clearly seen also in Fig. 8, that the answers of men and women are completely opposite. 


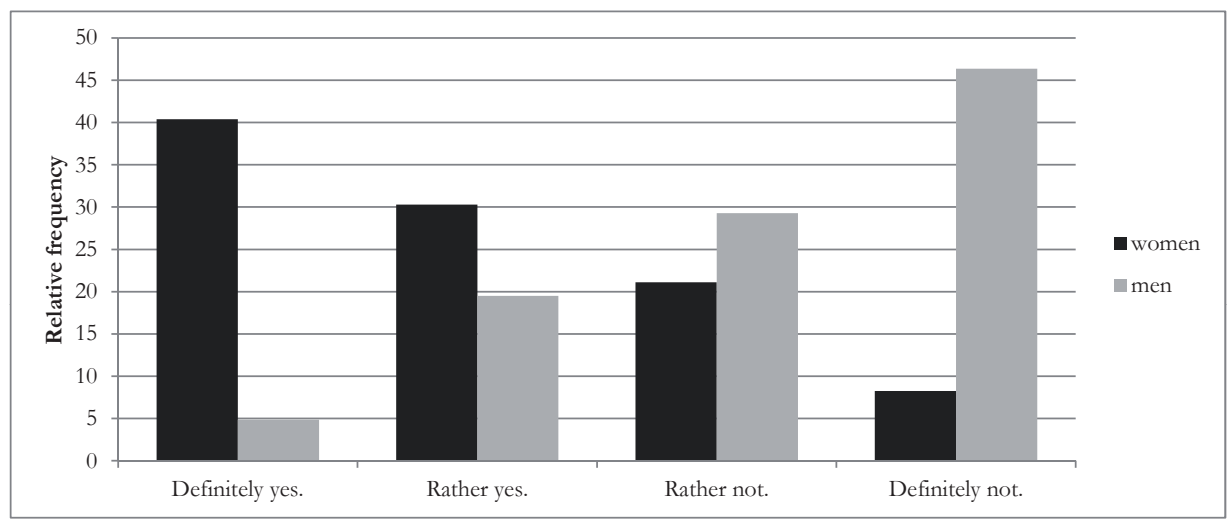

Fig. 8 - Opinion on quotas by men and women. Source: own processing, 2013.

\section{DISCUSSION AND RESEARCH LIMITATION}

Although the students have not yet many practical experiences, they have a clear opinion and attitude to issues of discrimination, equality and diversity. They are able to see the benefits of diversity that could be positive for future development of diversity management because the respondents are possible future managers or executive workers and these may have strong potential for making changes in society and business too. Nowadays the concept of diversity management and inclusion is in the early stage and its future depends on these people.

The respondents think that the most widespread discrimination is based on age, ethnicity and gender. But when they should determine what specific groups are the most suffering from discrimination, women and foreigners belonged to the least suffering groups. The most vulnerable groups are old people, young people and disabled people by them. It may be due to the fact that these young people are not thinking about discrimination so deeply and they better reflect the issue only after the greater specification of individuals groups of vulnerable people. The result could be that gender and ethnic problems on the Czech labour market will be still overlooked in the future. But the situation is still changing, globalization is widespread and the status of women in society is slowly improving.

The responses regarding gender quotas are strongly gender influenced. It is seen the clear difference between responses of men and women. But these results deffer from opinion of Czech female managers who are mostly against quotas. (Ihned.cz, 2013) The opinion of female respondents from this research may be subjectively imbued due to lack of information and experiences from practice.

The results of this paper may be considered as a background for a further more detailed research that could for example compare the opinion of potential future managers with opinion of real current managers in the Czech Republic. This survey is based on responses of only 150 respondents so it could be a pilot project for further survey with much more respondents and higher explanatory power. It would be interesting to compare these results with another foreign research results but in the current situation there was found no similar research for comparison. 


\section{CONCLUSION}

Diversity of population and labour force is becoming more and more significant in the Czech Republic. There is a high ratio of women (there are even more female than male citizens) and the ratio of older people is still increasing. Gender and age diversity are the most significant elements of diversity but it is possible that other elements of diversity such as ethnicity or mental and physical abilities will be also more important in the future.

Current students, future managers, have mostly enough information about diversity and about the problem of inclusion and have also own opinion on this. They mostly can define „diversity“ and its benefits very well. However, there is only small awareness about the term „diversity management". Future managers can feel what does it mean but they had never met it before at school or in press etc.

Future managers stated that the greatest benefit of diversity in business is a possibility of increasing creativity and innovation and increasing motivation, satisfaction and performance of employees. That confirms some results of European Commission research- SME Diversity Survey from 2008.

According to potential future managers the most widespread type of discrimination is discrimination based on age, ethnicity and gender. It deffers a little from results of European Commission survey that shows that the most widespread discrimination in CR is based on age, ethnicity and disability (not gender). The difference could be caused by the high ratio of women among respondents of this author's survey.

These respondents think that gender discrimination is very often in the Czech Republic but they do not think that women are the most suffering group of discrimination. According to them the most vulnerable groups are old people, young people and graduates and disabled people.

Answers regarding quotas for women were mostly positive. This result could be also caused by the high ratio of women in this survey because it was verified the dependence of answers on that who is answering the question (men or women).

In summary, young future managers' awareness of diversity and inclusion is not so wrong but it should be higher because it is an important topic for the future of whole society, policy and economics too.

\section{Acknowledgement:}

This paper was supported by University of West Bohemia in Pilsen from Project No. SGS-2012-028: Research of the influence of monitoring, evaluation and prediction of the organization processes development on the overall performance.

\section{References}

1. Ananthram, S., \& Chan, Ch. (2013). Challenges and strategies for global human resource executives: Perspectives from Canada and the United States. European Management Journal, 31(3), 223-233. http://dx.doi.org/10.1016/j.emj.2012.12.002

2. Bedrnová, E., \& Nový, I. (2007). Psychologie a sociologie rízení. Praha: Management Press.

3. Blatná, D. (1996). Neparametrické metody. Praha: VŠE.

4. CZSO (2011a). Gender Pay Gap. Retrieved March 22, 2013, from http://apl.czso.cz/pll/ eutab/html.h?ptabkod=tsdsc340. 
5. CZSO (2011b). Podíl populace ve věken 65 a více let. Retrieved March 21, 2013, from http://apl. czso.cz/pll/eutab/html.h?ptabkod=tps00028.

6. CZSO (2011c). Celková míra nezaméstnanosti starších osob. Retrieved March 22, 2013, from http://apl.czso.cz/pll/eutab/html.h?ptabkod=tsdde100.

7. CZSO (2012a). Obyvatelstvo podle státního občanství. Retrieved March 22, 2013, from http://apl. czso.cz/pll/eutab/html.h?ptabkod=tps00157.

8. CZSO (2012b). Počet žẹn na 100 mu乏̌ù Retrieved March 21, 2013, from http://apl.czso. $\mathrm{cz} / \mathrm{pll} / \mathrm{eutab} / \mathrm{html} . \mathrm{h}$ ?ptabkod=tps00011.

9. CZSO (2013). Mira barmonizované nezaměstnanosti, v členèni podle poblaví. Retrieved March 22, 2013, from http://apl.czso.cz/pll/eutab/html.h?ptabkod=teilm020.

10. Eger, L. et al. (2012) Diversity management: Comparison, the best practices of Visegrad countries. Plzeň: Nava.

11. European Commission (2008). Continuing the Diversity Journey: Business practices, perspectives and benefits. Retrieved March 21, 2013, from http://ec.europa.eu/culture/documents/ continuing_diversity_journey.pdf.

12. European Commission (2009). Discrimination in the EU 2009. Retrieved March 21, 2013, from http://ec.europa.eu/public_opinion/archives/ebs/ebs_317_fact_cz_en.pdf.

13. European Commission (2010). Poverty and social exclusion. Retrieved March 20, 2013, from: http://ec.europa.eu/social/main.jsp?catId=751\&langId=en.

14. European Commission (2013). Gender balance in decision-making positions. Retrieved March 21, 2013, from http://ec.europa.eu/justice/gender-equality/gender-decision-making/index_ en.htm.

15. Hubbard, E. E. (2004). Diversity management. Amherst: HRD Press.

16. Hubbard, E.E. (2011). The Diversity Scorecard: Evaluating the Impact of Diversity on Organizational Performance. New York: Routledge.

17. Ihned.cz (2013). Manažerky s kvótami pro ženy ve firmách nesoublasí, chbtěji vétši podporu pro matky. Retrieved May 29, 2013 from http://byznys.ihned.cz/c1-58541150-zeny-zeny-v-byznyselegislativy.

18. Kirton, G., \& Greene, A.-M. (2010). The Dynamics of Managing Diversity. A critical Approach. Oxford: Elsevier Ltd.

19. Knippenberg, D., Ginkel, W.P., \& Homan, A.C. (2013). Diversity mindsets and the performance of diverse teams. Organizational Behavior and Human Decision Processes, 121(2), 183-193. http://dx.doi.org/10.1016/j.obhdp.2013.03.003

20. Lančarič, D., Savov, R., \& Chebeň, J. (2012) Diversity Management as One of Solutions for Problems Caused by Demographic and Social Development in European Union (with focus on Slovak Republic). International business and economics review, 2012(3), 26-41.

21. Paříková, P. (2012). Pracovnich nabidek pro żdravotně postižené príbylo. Meziročně o trétinu. KarieraWeb.cz. Retrieved March 27, 2013, from http://kariera.ihned.cz/c1-57167170pracovnich-nabidek-pro-zdravotne-postizene-pribylo-mezirocne-o-tretinu.

22. Risberg, A., \& Soderberg, A.M. (2008). Translating a management concept: diversity management in Denmark. Gender in management: An International Journal, 63(3), 426-441. http://dx.doi.org/10.1108/17542410810897544 
23. Roosewelt, R. T. (1996). Redefining diversity. New York: AMACOM.

24. Roosewelt, R. T. (1999). Building a House for Diversity. New York: AMACOM.

25. Roosewelt, R. T. (2006) Building on the promise of diversity: how we can move to the next level in our workplaces, our communities, and our society. New York: AMACOM.

\section{Contact information}

Ing. Milena Jirincová

University of West Bohemia in Pilsen, Faculty of Economics

Husova 11, 30614 Plzeñ, Czech Republic

Email:milenaj@kpm.zu.cz. 